\section{US makes plea for Japanese SSC help}

Answer: "no", and an emphatic news conference - Bush expected to try one last time next month

\section{Tokyo}

JAPANESE official have said "no" as clearly as they know how to US requests for a major contribution to the construction costs of the US Superconducting Super Collider (SSC). The rejection - Japan's first official answer to the United States - came last week at a high-level meeting in Tokyo between US presidential science advisor D. Allan Bromley and Akiko Santo, director general of the Science and Technology Agency. But the door is not shut completely. There is still a possibility that Japan will decide to contribute when US President George Bush meets with Japan's soon-to-be-elected new prime minister in Tokyo next month.

Japanese financial support is vital to the future of the SSC. The US law that established the $\mathrm{SSC}$ project requires that at least one third of the more than $\$ 8,000$ million needed to build the collider must come from outside the US Federal government. Without a substantial Japanese contribution, this requirement will be very difficult, if not impossible, to meet.

And so a steady stream of top US officials have been visiting Tokyo to court the Japanese government. First to arrive in June last year was a large delegation of US scientists and representative of the Department of Energy (DOE) who called on all of Japan's science-related ministries and agencies. And US President George Bush has repeatedly asked Japanese Prime Minister Toshiki Kaifu to support the SSC whenever the two meet.

But the Japanese response has been decidedly cool. At the last US-Japan summit in July, Kaifu hinted to Bush that it would be very difficult for Japan to contribute to the SSC because the Japanese government's first priority at present is to renovate Japan's rundown university research system (Nature 352, 177, 18 July, 1991).

Japanese government officials cited very similar reasons in rejecting US requests for SSC support at last week's meeting. Santo said at a press conference after the two-day meeting that the Japanese side explained to their US counterparts that contribution to the SSC would cause "difficulties" because of budgetary constraints on government spending, and because of Japan's need to strengthen its basic research system, particularly in the universities.

When asked at the press conference to clarify if the Japanese explanation meant "no" to the US request, Santo confirmed that it did - a view which is echoed by officials of the Ministry of Foreign Affairs, who also participated in the meeting.

The rejection came despite last-minute offers from the US side that were clearly intended to sway the Japanese. At a press conference in Tokyo the day before last week's meeting, Bromley urged Japan's participation in the SSC project as "a full partner" and offered Japan's scientists a bigger role in managing the project (insufficient Japanese input is one of the key concerns of Japanese critics of the SSC).

On top of this, he announced that the United States will probably contribute financially to Japan's Human Frontier Science Program, something Japanese government officials have long been hoping for (see below). He also hinted at possible US support for the Intelligent Manufacturing System project proposed by Japan's
Ministry of International Trade and Industry, as well as the sixth generation computer project proposed by the same ministry.

All of this probably came too late to alter the Japanese position, which has been months in the making. But the Japanese veto is not final. It only represents rejection at the ministry level.A reversal of the decision at the "very top level" is still on the cards, a foreign ministry official says.

At the meeting it was agreed to leave final discussion of the SSC to the US-Japan summit meeting in Tokyo next month between Bush and Japan's new prime minister, who will be elected at the end of this month. Kiichi Miyazawa, a former minister of finance and fluent English speaker, is widely expected to get the job, and it is possible that his new administration will decide to support the SSC so as to start off on a friendly footing with the US administration.

David Swinbanks

INDIA

\section{Skinny cows no threat}

New Delhi

US STUDIES on the amount of methane - a potent contributor to the greenhouse effect - produced by Indian cows overstated their threat by a third because they assumed the Indian animals were as large as their US counterparts, a new Indian study finds. Researchers at the Council of Scientific and Industrial Research (CSIR), as part of an exercise to collect data for the 1992 world climate conference in Brazil, say that US researchers simply extrapolated US bovine measurements made "under very different conditions" from those

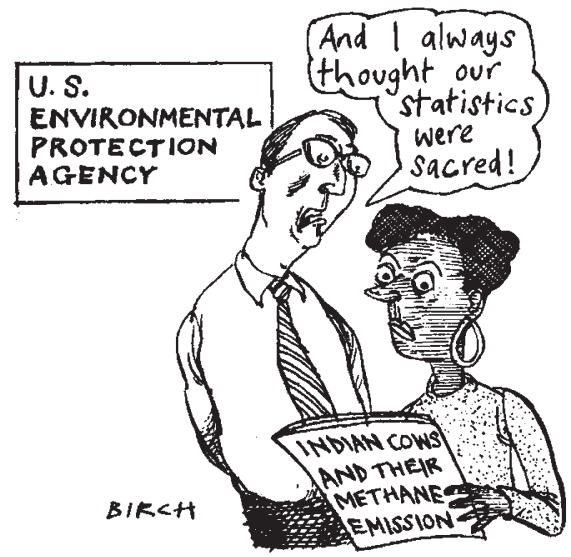

in India. Indian cows eat and weigh less than US cows. Similarly, methane emissions from Indian rice paddies are less than from US paddies of the same size because of smaller biomass of Indian rice plants. Based on field measurements, CSIR estimates that total Indian methane output is just over 10 million tonnes a year - less than a quarter of the $\mathbf{4 8}$ million tonnes a year that the US Environmental Protection Agency and Oak Ridge National Laboratory have calculated. K.S. Jayaraman

David Swinbanks 